Utah State University

DigitalCommons@USU

\title{
Livestock Markets and Risk Management Among East African Pastoralists: A Review and Research Agenda
}

\author{
DeeVon Bailey \\ Utah State University \\ Christopher B. Barrett \\ Peter D. Little \\ Francis Chabari
}

Follow this and additional works at: https://digitalcommons.usu.edu/eri

\section{Recommended Citation \\ Bailey, DeeVon; Barrett, Christopher B.; Little, Peter D.; and Chabari, Francis, "Livestock Markets and Risk Management Among East African Pastoralists: A Review and Research Agenda" (1999). Economic Research Institute Study Papers. Paper 170. \\ https://digitalcommons.usu.edu/eri/170}

This Article is brought to you for free and open access by the Economics and Finance at DigitalCommons@USU. It has been accepted for inclusion in Economic Research Institute Study Papers by an authorized administrator of DigitalCommons@USU. For more information, please contact digitalcommons@usu.edu.

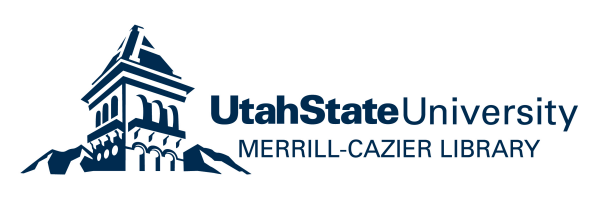


Economic Research Institute Study Paper

ERI \#99-20

LIVESTOCK MARKETS AND RISK MANAGEMENT

AMONG EAST AFRICAN PASTORALISTS:

A REVIEW AND RESEARCH AGENDA

by

DEEVON BAILEY

Department of Economics

Utah State University

3530 Old Main Hill

Logan, UT 84322-3530

CHRISTOPHER B. BARRETT

Department of Ag. Res. and Manag. Economics

Cornell University

Ithaca, NY 14853-7801

PETER D. LITTLE

Department of Anthropology

University of Kentucky

Lexington, KY 40506

FRANCIS CHABARI

Director
GTZ-Marsabit Development Progam

March 1999

(First draft-Comments appreciated, please do not cite without permission) 


\title{
LIVESTOCK MARKETS AND RISK MANAGEMENT
}

AMONG EAST AFRICAN PASTORALISTS:

A REVIEW AND RESEARCH AGENDA

\author{
DeeVon Bailey, Professor \\ Department of Economics \\ Utah State University \\ 3530 Old Main Hill \\ Logan, UT 84322-3530 \\ Christopher B. Barrett, Associate Professor \\ Dept. of Ag., Resource, \& Manag. Econ. \\ Cornell University \\ 351 Warren Hall \\ Ithaca, NY 14853-7801 \\ Peter D. Little, Professor \\ Department of Anthropology \\ University of Kentucky \\ Lexington, KY 40506 \\ Francis Chabari, Director \\ GTZ-Marsabit Development Program
}

The analyses and views reported in this paper are those of the author(s). They are not necessarily endorsed by the Department of Economics or by Utah State University.

Utah State University is committed to the policy that all persons shall have equal access to its programs and employment without regard to race, color, creed, religion, national origin, sex, age, marital status, disability, public assistance status, veteran status, or sexual orientation.

Information on other titles in this series may be obtained from: Department of Economics, 3530 University Boulevard, Utah State University, Logan, Utah 84322-3530.

Copyright (C) 1999 by DeeVon Bailey, Christopher B. Barrett, Peter D. Little, and Francis Chabari. All rights reserved. Readers may make verbatim copies of this document for noncommercial purposes by any means, provided that this copyright notice appears on all such copies. 


\section{LIVESTOCK MARKETS AND RISK MANAGEMENT \\ AMONG EAST AFRICAN PASTORALISTS: \\ A REVIEW AND RESEARCH AGENDA}

DeeVon Bailey, Christopher B. Barrett, Peter D. Little, and Francis Chabari

ABSTRACT 


\section{LIVESTOCK MARKETS AND RISK MANAGEMENT \\ AMONG EAST AFRICAN PASTORALISTS: \\ A REVIEW AND RESEARCH AGENDA ${ }^{2}$}

\section{Introduction}

The purpose of our Global Livestock CRSP project is to identify risk reducing alternatives for East African pastoralists. Many believe the level of risk faced by pastoralists is excessive and may even be increasing. Among the many candidate explanations for high and rising risk exposure are (i) limited and declining spatial refugia as population pressures, violence, and the gazetting of protected areas for environmental conservation have limited access to dry season grazing areas, (ii) substantial and seemingly increasing climatic variability, (iii) inadequate physical and institutional infrastructure to support asset or income diversification, (iv) and increased political instability in the region coupled with economic liberalization that has brought macroeconomic shocks and greater market price variability. Our own participatory risk mapping work finds that pastoralists themselves consider the condition of livestock markets, and especially the prices they receive in such markets, a major source of risk they face (Smith et al. 1999). An important intermediate objective of this project is therefore to describe accurately market conditions confronting pastoralists in the region and to identify market interventions or reforms that might reduce the market-related risks they face.

Our study area traverses an ecologically, ethnically and institutionally heterogeneous transect of approximately 750 kilometers, from Agere Mariam in southern Ethiopia south through Baringo,

\footnotetext{
${ }^{2}$ We thank Abdillahi Aboud, Layne Coppock, Solomon Desta, Simeon Ehui, Ahmed Mahmud, Stephen Sandford, and Kevin Smith for helpful discussions on this topic and Hussein Mahmoud and Sheila Nkonge for valuable research assistance. All remaining errors are ours alone.
} 
Isiolo, and Samburu Districts in northern Kenya. Although some animals from southern Ethiopia-especially north of Yabello in the study region--flow northward to Addis Ababa and sometimes on to export markets in the Arabian peninsula, Nairobi acts as the principal terminal market for livestock in northern Kenya and southern Ethiopia - and more generally for livestock from throughout Kenya, southern Somalia, northern Tanzania, even eastern Uganda. Cross-border livestock trade is substantial and seems to be growing rapidly in the Greater Horn of Africa (Little 1996). Moyale, on the Ethiopia-Kenya border, is a major catchment market for southern Ethiopia, and for small stock from Moyale District, Kenya. The main livestock movement corridor in our study area follows the dirt road from Moyale through Marsabit and Isiolo, where it becomes tarmac and proceeds southward to Nairobi. ${ }^{3}$ While some livestock are sold, slaughtered, and consumed in market towns along the transect, most are eventually sold in Nairobi, drawn by its metropolitan population and purchasing power. ${ }^{4}$

The purposes of this background paper are to (1) provide an overview of the state of the livestock marketing channel in the study area, based mainly on secondary data, (2) examine the relevant literature dealing with risk in livestock markets in sub-Saharan Africa, (3) and determine critical livestock marketing research needs in our study area of southern Ethiopia and northern Kenya and (4) introduce a conceptual framework that we think can usefully guide further empirical research. We also examine methodologies that could be used to evaluate the market risks faced by

${ }^{3}$ Livestock from the southwestern reaches of our study area, in Baringo and southwestern Samburu Districts, sometimes move through Laikipia or [Nakuru] and [down country toward highland markets and on to Nairobi.]

${ }^{4}$ The Nairobi meat market is the main outlet for slaughter cattle and smallstock. Numerous slaughter houses exist within and around Nairobi. A small meat market for camels has also developed and caters mostly to the growing number of Somali refugees coming to Nairobi. The estimates for daily camel slaughter is small (only about 30 head). The camels are mainly slaughtered at Athi River and the carcasses transported to Nairobi. 
pastoralists. This information will be used to determine what data and methodologies will be used in the livestock-marketing portion of the project.

In any review of the literature on livestock markets in semi-arid tropical Africa (SATA), it becomes immediately apparent that far more work has been completed dealing with livestock markets in West Africa than in East Africa. However, the conditions of pastoralists and livestock markets in both regions of Africa appear to be similar in important respects and the literature dealing with west African livestock markets is relevant to East Africa both in terms of the issues addressed and the methodologies used in the more recent literature. The literature cited in this paper is not exhaustive, but rather includes those pieces we consider most relevant to the present CRSP project in East Africa.

As the structure of this paper reveals, we think it useful to distinguish (i) analysis of market participants and their behavior, including aggregate manifestations of behavior as revealed in price and volume data, from (ii) analysis of the environmental, infrastructural, and institutional context in which market participants make marketing decisions. A primary reason we deem this distinction useful is that governments and non-governmental organizations (NGOs) can generally affect only participants' decision-making context, i.e., the incentives and constraints they face. Examining this context as a whole facilitates comparisons to identify where interventions will likely prove most effective. Based on our examination of the literature, our recommendation is that the livestockmarketing component of this project proceed in two stages. First, we should pursue a similar approach to the most recent literature evaluating livestock markets in West Africa using methodologies not yet applied to livestock markets in East Africa (e.g., investigating spatial market integration in the study area). This will require market data on both the Ethiopian and Kenyan sides of the border. Second, we should then address the behavioral and contextual questions largely absent 
from the existing literature on livestock marketing in SATA (e.g., the effects of quarantine ${ }^{5}$ on livestock price distributions and herder welfare, or allocation of the price risk faced by pastoralists' by source, since the appropriate remedy is conditional on the root cause of price risk) and approach longstanding questions (e.g., pastoralists' price elasticity of livestock supply, the structure of the livestock marketing channel) using analytical methods heretofore absent from the literature on livestock marketing in SATA.

\section{State of the Regional Livestock Industry: The Market Participants}

The livestock marketing system is made up of pastoralists who raise animals, traders who buy animals in and around periodic markets throughout the rangelands, hoping to sell them at a profit elsewhere, transporters, local butchers, terminal market abattoirs in and around Nairobi, meat wholesalers, and, ultimately, consumers. A detailed outline of marketing channels in the Kenyan part of the study area for different species is provided by Njiru (1983), and secondarily by the reports of the Government of Kenya/ GTZ Range Management Handbooks for the region (for example see Ministry of Agriculture, Livestock Development, and Marketing 1993). ${ }^{6}$ Because we were unable to spend sufficient amounts of time in southern Ethiopia and generally found scant secondary data or reports on the Ethiopian livestock industry pertinent to our study area (important exceptions are Fekade 1994; Mariam 1993; and Edwards and Mesfin (1996)), most of this section focuses on the Kenya side of the border. This highlights one area in need of research - basic descriptive analysis of the southern Ethiopian livestock industry is presently lacking. Some of this gap hopefully will

\footnotetext{
${ }^{5}$ Quarantines are an issue for livestock moving towards Nairobi but are not an issue for livestock moving from southern Ethiopia to Addis Ababa (Mahmud (1999)).

${ }^{6}$ Little (1996) provides a good, parallel treatment of the competing marketing channel from southern Somalia through Garissa and on to Nairobi. The basic organization of the marketing channel is the same across these distinct corridors.
} 
be filled by the current OSSREA (Organization for Social Science Research in Eastern and Southern Africa)/BASIS study of cross-border trade, which is collecting livestock marketing data on the Ethiopian side (see Little et al. 1998).

\section{Pastoralists}

The foundation of the livestock industry in the study area is the pastoral herders who live on products provided by their livestock (e.g., milk, blood, and meat) and sell livestock when cash is needed or when necessitated by climatic conditions. ${ }^{7}$ Pastoralists hold animals for a multitude of reasons. Livestock are a form of productive capital, providing a stream of desired goods and services, including milk (the primary good for most pastoralists in our study region), blood, manure, transport, and traction. They also serve as an important store of wealth and insurance, functions that are extremely important in the absence of well-developed rural financial markets and given significant covariate risk due to climate, civil unrest, and epidemiological shocks. Sometimes this wealth is consumed directly through slaughtering and meat consumption, but more often livestock are sold and the proceeds used to purchase grain, pay school fees, etc. The modern economics literature generally understands this as consumption smoothing (Binswanger and McIntire 1987, Swinton 1988, Bromley and Chavas 1989, Fafchamps et al. 1997). The importance of animals as stores of wealth is also reflected in social institutions surrounding marriage and inheritance, in which livestock play prominent roles. Indeed, the largest single allocation of livestock that a male herder is likely to make in a lifetime is for bridewealth at marriage, which exceeds 15 cattle and numerous small stock in parts of the study region. This points toward the considerable sociocultural functions,

\footnotetext{
${ }^{7}$ We should point out that our discussion of livestock marketing will focus almost exclusively on the meat industry, ignoring issues specific to the dairy industry. The reason is that pastoralists in our study region rarely sell productive dairy cattle and the breeds they keep are not especially well-suited to peri-urban dairying, so almost all sales are destined for slaughterhouses. East African dairying is studied in detail by, among others Ehui, Delgado, Nicholson et al.
} 
beyond the purely material uses, of livestock in the study region, although some of these institutions are changing. For example, in parts of Baringo District, Kenya marriage payments in the form of cash are partially substituting for livestock payments. Nonetheless, livestock are a source of prestige, a means for extending and investing in complex networks of social obligations and reciprocity that mitigate risk, and a part of rites of passage to adulthood.

The orientation of pastoral herders to keep livestock as their main source of food (milk) has important implications for herd structures in the region and, consequently, for strategies to increase market off-take rates. Unlike commercial beef herds in the USA, pastoral cattle herd structures are strongly biased toward female animals, especially mature milk animals (cows) rather than beef animals (steers and bulls). This bias in herd structure can facilitate relatively rapid animal recovery after drought- or disease-induced 'shocks' to the herd. Little shows in the Baringo part of the study region that typical herd structures include more than 60 percent female animals (not including calves up to 1 year old), and only 4 percent bulls, 10 percent immature bulls (over 1 year old), and 7 percent steer (Little 1985:149). Data from elsewhere in the study region generally supports this pattern, although the bias in female animals is even higher among the Rendille of Marsabit District, Kenya. For example, in this area the IPAL project found that female camels constituted 72.4 percent of the adult herd, while the percentages for adult cattle, sheep, and goat herds and flocks are, respectively, 79.6, 77, and 77.5 percent (IPAL 1984). In short, pastoral herds in the study region are structured to provide supplies of milk, high rates of reproduction, and rapid herd recovery following disasters; annual herd off-take rates that exceed 8 or 9 percent can compromise these functions (It is unknown how much herd structures in the region have changed in the past 10 years as the result of increased commercialization). The implications of these kinds of herd and flock structures is that the available supply of beef animals is far less than most development planners acknowledge. These are the 
animals that traders and urban consumers most desire and which herders are most willing to sell, although they possess fewer of them. The willingness of herders to dispose of productive female animals, the largest proportion of the herd, is usually a sign of extreme economic and social stress. The supply response of livestock producers is a critical component of any study of livestock markets in SATA since orderly marketing depends on a predictable response by buyers and sellers to different economic conditions. That livestock serve multiple purposes-some of which conflict with maximal herd off-take strategies - complicates pastoral marketing behavior. In addition, since different members (e.g., husbands and wives) of the household may have different disposal and use rights to the herd, intra-household relations and tensions can constrain sales of what might be interpreted as 'surplus' animals. The multiple and, in some cases, overlapping rights of different household members to the family herd is well recognized (see Ensminger 1992; Hutchinson 1996), but virtually no empirical attempt has been made to assess its impact on pastoral marketing patterns. Negotiations take place between husbands and wives (and, in some cases, sons) regarding the sale of family livestock--especially when a wife(s) has economic rights to the animal--but the outcome of these on off-take rates and marketing decisions is poorly understood. The project anticipates addressing this issue through its household surveys and ethnographic inquiries.

Sandford (p. 202 (1983)) suggests there is no “. . . universal proposition about the supply response of pastoralists to changes in the prices of their outputs." Sandford (1983) also attempted to rationalize the motivations of pastoralists in their livestock marketing decisions by reasoning that in an economy, such as SATA, where few goods are available for purchase that livestock are sold mainly to meet obligations that require cash such as for schooling or taxes, but that permanent changes in prices should generate an expected (though modest) supply response. Pastoralists' supply responsiveness hinges on the multiple motivations pastoralists have for either holding or selling 
livestock. It also should be remembered that pastoralists also frequently use the market to repurchase animals for their own herds, often selling when prices are favorable and repurchasing when they are low. The greater the role of social considerations in stocking decisions with few viable investment and asset options for herders, the lesser the expected price or income elasticity of supply (Ministry of Planning and National Development; and Coppock (1994)). Conversely, the greater the wealth store and insurance motives for holding livestock and the greater the asset and investment options for herders, the greater the expected response of pastoralists to price and other market shocks (Reardon, Matlon, and Delgado (1988); and Reardon, Delgado, and Matlon (1992)). And the greater the importance of the stream of benefits (milk, etc.) produced by animals, the more responsive will supply be to changes in animal productivity and the livestock/grain terms of trade.

Fafchamps and Gavian (1997) demonstrate that livestock markets in SATA are responsive to large demand shocks but they also demonstrate that livestock markets in West SATA are poorly integrated. However, the supply response to income shocks is less clear and may counter to some degree that livestock are held as a form of self insurance in some parts of SATA. For example, Fafchamps, Udry, and Czukas (1996) reported that livestock sales were much smaller than anticipated in Burkina Faso during periods of drought. They speculated that poorly integrated livestock markets may account for why livestock may not be a desirable hedge against income shocks in SATA.

Fafchamps (1998) concludes that there are two reasons why producers hold onto livestock in SATA even when their animals may die during periods of drought. First, producers "... desire to smooth consumption when livestock make an essential contribution to household income and 
other assets are not available." ${ }^{\prime 8}$ Second, that producers may be hoping to realize higher prices for their livestock when livestock supplies are diminished (i.e., producers realize that the demand for livestock is inelastic). Fafchamps(1998) argues further that the relative strength of these two forces depends on how inelastic the demand for livestock is and also the degree of market segmentation (integration).

So, the multiple roles played by livestock necessarily complicates understanding of pastoralist behavior. While the prevailing wisdom is that the price elasticity of livestock supply is quite low owing to the multifaceted use of animals by pastoralists, the apparently limited price responsiveness of pastoralists may result from animals' multiple roles in response to the multiple institutional, infrastructural, and environmental obstacles they face. Whether the increasing monetization of pastoral economies and recent or prospective changes in complementary systems (e.g., rural finance, resource tenure) will lead to fundamental changes in pastoralist livestock marketing patterns remains an untested hypothesis, and one on which we envision this project working.

Much of the past literature has suggested that the issues of supply response, and consequently prices and market risk, can not be separated from the effect of rainfall and social and economic reasons for large herds of livestock. Sandford (1982), for example, shows that over a drought-todrought cycle (approximately 5-7 years in most parts of our study region) the costs of 'understocking,' in terms of losses in herd productivity and benefits, in good years to approximate a constant stocking rate exceeds the economic losses from drought-induced herd crashes. This pattern, of course, will vary according to local ecological, economic, and other variables, but it does

\footnotetext{
${ }^{8}$ Fafchamps (1998) argues this is especially true for pastoralists whose income is mostly from livestock an who are unable to accumulate grain because of their nomadic lifestyle.
} 
partly explain why pastoralists are reluctant to de-stock through market sales during non-drought years. While researchers have continued to acknowledge the central role of drought in pastoral herd management decisions, they have also addressed more fully other economic reasons why pastoralists continue to hold livestock as their principal form of wealth. For example, Coppock's comprehensive 1994 study of the Borana Plateau in southern Ethiopia suggests that while significant cultural and structural barriers exist, banking offers additional alternatives for pastoralists for diversifying their wealth and, hence, reducing the income risk they face. Coppock (p 257, (1994)) also suggests that "Research into risk management of animal assets may be very timely for systems under increased population pressure." More recently, Fafchamps (1998) contended that unless herders “. . . have access to alternative savings instruments so that they can liquidate livestock if they fear losing animals ... they will tend to cling onto their assets as - highly imperfect -- forms of self-insurance. Consequently, making alternative investments available to pastoralists appears to be an important component of any strategy designed to decrease their risk and research is needed to determine which non-livestock investments will be acceptable and successful for pastoralists. If livestock become less important as a means of self insurance, then reducing the market risks faced by pastoralists should increase offtake, thereby lowering stocking rates to levels that may reduce widespread losses during droughts and, thus, stabilizing livestock throughput volumes, enhancing incentives to invest in meat processing capacity.

Marketing patterns are crucial to pastoralist welfare for a simple reason. In the difficult natural environment of our study area, climatic and disease risk lead to relatively high mortality rates if pastoralists are unable to sell off animals preemptively. For example, new data from southern Ethiopia using household herd history recall information show that from 1980-97, mortality on average accounts for more than seven times the gross reductions in herd sizes accounted for by sales 
(Desta, personal communication). ${ }^{9} \quad$ Figure 1 shows that even in good years, mortality always dominates marketing as the regulator of herd sizes. While stocking rates necessarily vary with climatic and ecological conditions, the fact that mortality rather than marketed offtake serves as the primary adjustment mechanism reflects enormous loss of wealth in the system. A central aim of this project is to find ways to empower pastoralists to convert a significant portion of gross herd reductions from deaths into sales, and thereby capture considerable lost wealth with which to ensure food security, invest in health and education, and enable human development and conservation of valuable rangeland ecosystems.

\section{Traders}

As a social and economic category, livestock traders encompass a multitude of different actors, from small-scale 'bush' traders to market brokers to large urban-based merchants with transport and considerable capital (see Little 1992). At the lowest levels in the market chain traders purchase animals from pastoralists up country and sell them, directly or indirectly through colleagues or secondary buyers, to processors in and around Nairobi and other terminal markets. Their business is arbitrage, trying to earn profits by buying at low prices in areas and times of excess supply and selling at higher prices in places and times of excess demand. A cohort of competitive arbitrageurs is essential to efficient marketing arrangements. Traders are the vehicles by which price signals in one market are transmitted to another, thereby propagating information on location-specific (demand or supply) shocks throughout the broader region. Arbitrageurs' costs relate primarily to transport, storage, information, finance and risk. As these costs escalate, trader activity falls, leading to greater

\footnotetext{
${ }^{9}$ This does not suggest that economic losses from drought are larger than gains resulting from "normal" offtake since animals which die during drought periods could have been sold only at unusually low prices. This is illustrative, however, of the potential opportunity costs associated with boom and bust cycles in the study area.
} 
spatial and intertemporal price disparities and greater chance for the exercise of market power by one or a small number of traders.

In the large urban markets, such as those in Nairobi, market brokers (often called dilaal) operate to match urban-based buyers, such as butchers and processors, with sellers who may be transporting animals from the range areas. The broker charges a fee to the seller of as much as 3 percent of the animal's market value, in order to match him/her with a buyer. The broker may also charge a fee to the buyer. This practice reduces market uncertainties for both the seller and buyer. The principle of trust is important in such relations. Boran traders from northern Kenya, for example, often use Boran brokers in Njeru market, Nairobi, since they feel they can rely on them to find the best prices for them (Little found in 1996 that Boran traders had placed a Boran broker in Njeru market to help them negotiate fair market prices). Somali traders often do the same. In the Dagoretti market of Nairobi, where auctions take place and Kikuyu, Kamba, and Maasai buyers are dominant, up-country traders often feel they still not receive fair prices and claim there is market collusion among groups of buyers even at auctions. Many Northern Kenyan traders and herders prefer to use Njeru market to Dagoretti, because their market contacts are better there.

Despite their centrality to efficient market operations, traders are commonly scorned by producers, including pastoralists in our study region, and scholars (e. g. Swift(1979)) as exploitative. This is particularly so when traders are from minority ethnic groups (e.g., Burji or Somali traders in Marsabit District) and are seen as 'outsiders' who capitalize on the market disadvantages of local herders. For example, in 1999 increased tensions have been directed at traders of certain ethnic groups who operate in Marsabit and Moyale Districts, Kenya (Kevin Smith, personal communication). Ethnic traders often are used as 'scapegoats' when there is an economic downturn. Where the institutional or infrastructural context—e.g., an absence of open auctions, poor roads that 
impede trader traffic, etc.- - forces pastoralist sellers to confront a single, monopsonistic buyer (or a small number of potentially collusive buyers), traders may indeed "exploit" pastoralists, in the sense of offering them a price that leaves a significant, positive economic profit for the trader. In some cases, however, the low price offered by the trader may be a function of the extremely high transport costs in the area; in some cases, it may be the transporters who are reaping the greatest economic benefits, since many traders do not own their own lorries and must hire transport. But where institutions and infrastructure render livestock trading and transport competitive, marginal profits in trading quickly go to zero, with only the most efficient and agile traders earning sustainable profits. There appears to be little evidence that traders are on average able to capture “abnormally high” returns (Staatz (1979); Holtzman, Stattz, and Weber (1980); Herman (1983); Holtzman and Kulibaba (1994); Holtzman, Kulibaba, and Stathacos (1992)). Sandford (p. 206 (1983)) reports that livestock marketing margins appear consistent across countries and “. . . that there are [no] startling improvements to be gained in raising returns to producers ... by reorganizing or regulating the marketing chain between the producer and the point at which sales of live animals are made to butchers or slaughter houses.” In the same spirit, Staal and Shapiro (1994) conclude that price liberalization in Kenyan dairy markets improved producer profits because the marketing channel is workably competitive. Holzman and Kulibaba (1994) suggest that while traders may have a "competitive edge" resulting from superior market information, this advantage can best be eliminated through enhancing competition and maintaining marketing infrastructure and information systems. For example, eliminating barriers to credit access that impede entry into trading and improving the quality of publicly available livestock market information could reduce this advantage. 
While traders may have some competitive advantage compared to typical pastoralists, they still face considerable risk. For example, In the Nairobi market northern Kenyan livestock often compete with animals coming in from Tanzania and Somalia. The flow of animals from these crossborder markets depend on a range of factors (border closures, drought and market conditions in these countries, etc) that are difficult to predict and can change rapidly. This increases the risk faced by the up-country trader who may arrive in Nairobi with cattle purchased in northern Kenya only to find thousands of animals have arrived from another country.

Casual observation suggests that many of the most successful traders have been able to procure lorries, and thereby overcome regular transport bottlenecks, have access to considerable cash savings and lines of credit with which to finance purchases, and have strong informational and distribution networks - both up country and in Nairobi — often through ethnic (especially Somali) and clan ties. Given considerable mobility barriers within low-income agricultural marketing channels, the emergence of highly profitable pockets within the marketing channel is commonplace, especially in bulk, long-distance trading (Barrett 1997).

Under current conditions of poor market information, infrastructure, insecurity, and unfavorable market access by herders, ethnicity tends to assume an important role in market transactions. Since formal market contracts and formal credit are rarely used, trust assumes considerable importance in market transactions. To minimize transaction costs associated with acquiring market information, market fraud and enforcement, and weak credit markets, traders and herders often deal with market actors from their own or closely related ethnic groups. This pattern tends to become even more important as political insecurity accelerates, a pattern that Peter Little has observed in northeastern Kenya and southern Somalia (Little 1996) The importance of ethnicity also seems especially important in long-distance livestock trade (see Cohen 1965). 


\section{Processors}

Slaughter and meat handling and distribution facilities are a critical link between the livestock trader and the final consumer. Orderly markets depend on these facilities to efficiently move products through the final stages of the marketing channel. If demand and supply do not match in the channel, wide swings in price can take place. ${ }^{10}$ Even if livestock supply from pastoralists and meat demand from final consumers are reasonably price elastic, capacity constraints in the marketing channel can create inelasticities of meat supply and animal demand that result in dramatic price fluctuations even in the presence of perfect competition. As a consequence, matching slaughter and distribution capacity with the demand and supply of meat is a fundamental task of any livestock marketing system. This matching can be done effectively only if communications and transport infrastructure enable good market information availability and responsive movement of animals and complementary products across space and time, ${ }^{11}$ and if supply and demand are reasonably predictable much of the time (e.g., not prone to severe disruption due to civil strife or disease epidemics).

Moreover, the large capital outlays required to build and maintain processing and distribution systems involve significant, unrecoverable ("sunk") costs and result in increasing returns to scale in distribution and processing over a fair range of quantities. Highly variable and often low throughput volumes can thereby discourage private investment in processing and distribution capacity, resulting in bottlenecks in the marketing system that lead to greater price variability. A

\footnotetext{
${ }^{10} \mathrm{An}$ example is the recent glut of hogs in U. S. markets which have outstripped the ability of slaughter facilities to effectively handle them. As a result, hog prices recently dropped to their lowest absolute level of the past 40 years (about $\$ 0.20 / \mathrm{kg}$.).

${ }^{11}$ For example, knowledge regarding livestock inventories, relative prices, and the number of livestock expected to move to market in the near and longer terms are essential for planning purposes.
} 
vicious cycle often erupts under such circumstances, whereby volatile market conditions discourage both pastoralist livestock producers and prospective entrants into meat distribution and processing, thereby rendering market conditions still more volatile. 
Status of the Kenyan Meat Industry

The state-owned Kenya Meat Commission (KMC) ${ }^{12}$ was established in 1960 and operated slaughter and canning facilities up to 1987. The Athi River plant closed in 1987, reopened in 1989 and closed again in 1993. KMC, a legal monopoly and monopsony in Kenya's livestock industry, administratively set livestock and meat prices. It incurred substantial operating losses and was often significantly in arrears in payments to livestock suppliers. As with many SATA food marketing parastatals, KMC kept prices low to appease a vocal, urban constituency, at considerable cost to livestock producers in pastoral areas. The legacy of administrative livestock pricing led to under investment by private traders in transport and processing capital necessary to maintain or expand capacity in the sector, and the collapse of much of the modern ranching industry in Kenya (Mbogoh 1997, Mutea and Lelei 1994). For example, Little (1992) posits that policies as far back as the colonial period which discouraged mobile traders and encouraged trading at administrative posts developed a local dependence on large market towns outside of local districts. Coupled with growing insecurity in the north, the number of livestock traders appears to have fallen sharply, at least until meat and livestock price deregulation in 1987. The legacy of that era nonetheless persists in the form of weak supporting infrastructure, limited private distribution and processing capacity, and widespread claims of local trader monopsony in animal purchasing (Mbogoh 1997).

\footnotetext{
${ }^{12}$ At one time the Ethiopians had a paarastatal Ethiopian Livestock and Meat Corporation (ELIMCO) that was a less prominent entity than KMC was in Kenya. While ILIMCO purchased animals at administratively-determined prices which were adjusted roughly every three months, it never had either official or de facto monopsony power. Consequently, it did not eliminate investments by private traders as much as was the case in Kenya with the KMC. ELIMCO would generally buy from the southern and eastern parts of Ethiopia primarily for export. It owned large holding areas all of which were sold to private parties in the early 1990s. ELIMCO itself was closed in 1994 (Mahmud (1999)).
} 
A three-volume feasibility study was completed for the KMC in 1989 by a firm based in the United Kingdom (Union International Consultants (1989)). ${ }^{13}$ The report recommended a restructuring of the KMC into a new commercially-oriented entity called the Kenya National Meat Corporation (KNMC) with a high proportion of the corporation being sold to private shareholders during the fourth year of the KNMC 's operation. The report recommended upgrading the existing facilities at the $\mathrm{KMC}$ rather than constructing new facilities and also suggested getting the Athi River plant back into operation slaughtering animals and canning meat for the domestic and export markets as soon as possible. The consultants also suggested operating the Mombasa slaughter facility and the Nairobi and Mombasa distribution depots to supply the domestic market while maintaining the livestock holding grounds at both Mombasa and Nairobi abattoirs to help maintain needed supplies. The report predicted that KNMC would be profitable by the third year earning a profit of $7 \%$ of gross sales. The KMC facilities at Athi River (near Nairobi) and Mombasa remain closed although the Athi River facilities were fully reconditioned by the Mitsubishi Company. In late 1998, KMC was put into receivership and its future remains unclear even though private companies/associations are offering to buy the facilities.

Another, more recent study (undated but containing 1994 statistics $^{14}$ ) contains an outline of current meat sub-sector problems and proposed future development alternative and policies. The report predicted a meat deficit of 130,000 metric tons in Kenya by 1995 that could only be met by imports. This and other such predictions have failed to materialize-in fact, meat prices in Nairobi have been relatively stable during 1995-1998--suggesting that available national statistics are not

\footnotetext{
${ }^{13}$ Volume 1 of the study presented an overall strategy and business plan for KMC, volume 2 examined the cattle and beef sectors, and volume 3 contained appendices.

14“"Meat Sub-Sector Review" in Kenyan Government/Donors Agricultural Sector Review.
} 
reliable. Among other reasons, government estimates have difficulty accounting for the considerable unofficial imports that flow through the porous national borders to the north (Ethiopia), south (Tanzania), and east (Somalia).

In 1993, GTZ-Marsabit Development Programme(GTZ-MDP) sponsored a feasibility study for a proposed abattoir at Isiolo and found that a medium-sized facility could be profitable (Surtech Consulting Engineers (1993)). The study suggested that a canning facility be part of the complex and that a government subsidy arrangement be worked out to help facilitate emergency offtake. The study also suggested that livestock producers and traders from the region be allowed to buy shares in the project to ensure a regular supply of slaughter stock. A holding company, Frontier Meat Products was registered to undertake the project about three years ago but there has been no further progress.

These findings suggests significant risk exists for those considering investing in high-volume slaughter and distribution facilities in the study area (e.g., KMC has closed and another plant has failed to materialize). A major source of this risk is the inability to ensure adequate supplies to operate the facilities efficiently. If firms are unable to manage slaughter inventories effectively, then costs (risks) will continue to be high and will discourage investment in these types of facilities. Fortunately, small-scale slaughter facilities in and around Nairobi —although with no canning capacity — have recently sprung up to meet Nairobi's growing demand for meat. Aside from public subsidies, the most likely stimuli to private investment in expanding the distribution and processing capacity of the livestock marketing channel are the provision of timely and accurate market information, available to both buyers and sellers, and the removal of barriers which hinder the flow of products. Such reforms would facilitate the effective supply management necessary to operate commercially viable meat processing facilities. 


\section{Price Patterns and Market Integration}

One of the core tools of markets analysis is market integration testing using price series. Advances in time series econometrics have spawned much renewed interest and advances in market integration testing methods in recent years (Barrett 1996, Fackler and Goodwin 1999, Li and Barrett 1999). To the best of our knowledge, no one has yet applied contemporary methods to east African livestock markets. Fafchamps and Gavian (1997) used one such method — the parity bounds model — to study spatial livestock market integration in Niger, and that study represents the current stateof-the-art in the study of African livestock market integration.

Our initial results using high-frequency (daily) data from Marsabit, Moyale, and Nairobi collected by GTZ-MDP indicates that price and basis risk (price differentials between market locations), as represented by coefficients of variation, are very high (Barrett et al. 1998). This suggests prices in spatially separated locations along the transect may not be well integrated. The consequences of loosely integrated markets or segmented markets are typically increased price risk and allocative inefficiency since local shocks are not smoothed by the aggregate market. Fafchamps (1998) also suggests that if markets are not spatially integrated that wealthy persons will “. . take speculative positions during droughts, thereby compounding pasture degradation." Thus, the question of whether spatial markets in the study area are integrated needs to be addressed at the outset of our study.

A related question of particular interest to us is the decomposition of the price risk faced by pastoralists into distinct components - local price risk related to the dispersion of prices within a periodic market on a given day, basis risk (i.e., variability in price differences between locations), and terminal market price risk. The appropriate intervention, if any, to reduce the tremendous price 
variability evident in northern Kenyan livestock markets depends fundamentally on the source of that risk. We hope to address this issue directly in the context of this project.

\section{The Environmental, Infrastructural, and Institutional Context \\ for Livestock Marketing}

Choices made by market participants are conditioned by the context in which they make decisions. Environmental conditions-e.g., rainfall, forage availability-affect livestock productivity and therefore animals' value. Infrastructural conditions relating to transport, communications, holding grounds, etc. affect the costs borne by pastoralists and traders in moving animals from pasture to terminal markets and slaughterhouses. Marketing behaviors at all levels in the channel are also influenced by institutional conditions surrounding the mechanisms by which parties to an exchange obtain information and arrive at a price, by which contracts are enforced, by which property rights are protected and physical security ensured, and by which animal disease is prevented or controlled. Governments and NGOs often have some ability to influence these contexts and thereby to influence the structure, conduct, and performance of the livestock marketing channel. This section of the paper focuses on these issues.

\section{Drought and Livestock Cycles, and Famine}

While often overlooked in economic studies, environmental conditions play an important role in livestock marketing in east Africa. Since a primary role of livestock is as a productive asset generating milk and calves (to a lesser extent blood, manure, and transport or traction power), and since animal productivity has a strong, positive relation to the condition of the range ecology in pastoral systems, environmental conditions necessarily affect demand for and supply and prices of livestock. Moreover, environmental conditions can affect marketing operations, particularly 
transport and disease control, that affect the costs and therefore the behavior of market intermediaries.

The level of rainfall is extremely variable in East Africa (Coppock (1994) and Bille (1983)). For example, rainfall in Marsabit, Kenya was $1443.8 \mathrm{~mm}$ in 1997 but only $320.1 \mathrm{~mm}$ in 1996 . The coefficient of variation (CV) for rainfall at Moyale between 1991 and 1997 was 242\% (Kenya Meteorological Department). ${ }^{15}$ Rainfall also appears to be closely linked with elevation. For example, Coppock (1994) reports that annual rainfall in southern Ethiopia increases by about $64 \mathrm{~mm}$ for every $100 \mathrm{~m}$ in elevation. Variations in rainfall also need to be captured at daily scales, since monthly and annual figures often mask climatic risks stemming from very uneven daily distribution patterns (i.e., rain events may be concentrated in only a few days of the month).

The connection between rainfall levels and the flow of livestock to markets in the study area as well as all SATA is critical since pastoralists tend to build herds during wet years and drastically deplete their herds during periods of drought (Konczacki (1978); Sandford (1983); Livingstone (1991); Little (1992); Franke (1982); Toulmin (1994); Coppock (1994); Fafchamps, Udry, and Czukas (1998)). During dry periods, animal productivity falls, so the value of livestock to pastoralists falls and the need for cash with which to purchase grain (a cheaper source of essential kilocalories and macronutrients than meat) increases, fuelling regular, sharp increases in livestock supply. This shift often outstrips the marketing and processing capacity in the system, leading to disorderly marketing and large absolute price declines (Konczacki (1978); Njiru (1983); Livingstone (1986); Little (1992); Holtzman and Kulibaba (1994); Holtzman and Kulibaba (1994); and

\footnotetext{
${ }^{15}$ Coppock (1994) points out that 50 to 60 years of data are probably required to determine accurate rainfall patterns. Consequently, our for Moyale need to be interpreted with some caution. For example, Coppock's (1994) CV for rainfall at Moyale between $1980-89$ was about $52 \%$
} 
Fafchamps and Gavian (1997)). ${ }^{16}$ Furthermore, the increase in demand for basic grains during dry periods often occurs when grain stores are low and/or in dry years of poor grain yields, leading to relatively rapid inflation in grain prices and, combined with falling prices for livestock, potentially disastrous swings in the terms of trade against pastoralists (Swinton (1988); Njiru (1983); Little (1992); Hotlzman and Kulibaba (1994); Toulmin (1994); and Fafchamps and Gavian (1997)). Livestock/grain terms of trade are thus a crucial indicator of pastoralist food security in the region (Little 1996).

Livestock cycles, defined as systematic rises and falls in livestock numbers over a period of years, are common throughout the world (e.g., Rosen, Murphy, and Scheinkman (1994)). ${ }^{17}$ However, the consequences of livestock production cycles in the developing world, especially SATA, are more severe than in the developed world because these cycles are often associated with drought and famine (Reardon, Matlon, and Delgado (1988); Sen (1981); Webb, von Braun, and Yohannes (1992); and Coppock (1994)) and because livestock systems rely more heavily on extensive grazing than on feedlot operations, so animal productivity is more closely tied to climatic and ecological shocks than in industrial livestock systems.

There is a long history of livestock cycles in Africa characterized by “. . cycles of drought, range degradation, destocking of animals, range recovery, and restocking of animals, followed by

\footnotetext{
${ }^{16}$ While there is agreement that the short-run effect of drought is to reduce prices by increasing offtake (e.g., Doran, Low, and Kemp (1979); and Sandford (1983)), the longer run effects of successive years of low rainfall appear to bring generate a different outcome. For example, Fafchamps and Gavian (pp. 271-2 (1997)) report that the effect of a single shock in rainfall is that "... good rains raise prices in the first year but depress them later; bad rains have the opposite effect." This suggests that more (less) animals are held for breeding and grazing initially when adequate (inadequate) moisture is available which leads to increased (decreased) beef production in subsequent years.

${ }^{17}$ It is not unusual for livestock producers to build herds in the face of rising prices in the course of a normal cycle. For example, the number of females in the U. S. cattle herd rose sharply in the early 1990s even as cattle prices rose (Anderson, Robb, and Mintert (1997)). But, the U. S. cattle cycle is driven mostly by prices and biological lags in supply response while African cycles appear to be driven primarily by drought (Coppock (1994)).
} 
a new cycle of drought and recovery" (Fafchamps 1998). Losses during periods of drought can be extremely large on a relative basis. For example, Little (1992) reports that herders in some locations of northern Kenya lost as much as $70 \%$ of their herd during the drought of 1984 . Livingstone (1986) reports similar large losses in Kenya during the drought of 1961-62.

Pastoralists have often been viewed as somewhat peculiar in that some researchers believe that livestock are used by pastoralists as their principal store of wealth rather than as incomegenerating capital (Doran, Low, and Kemp (1979); Coppock (1992); and Coppock (1994)). However, the peculiarity may be in the fact that income from livestock assets in pastoral Africa is in the form of products produced from the livestock themselves rather than in cash obtained from the sale of livestock. If so, economic theory suggests that a capital asset will be held until its income generating value falls below its salvage value. Consequently, pastoralists may hold livestock even in the face of rapidly declining prices if the value of livestock products exceeds what the animals could be sold for. This complicates the study of pastoralists' supply response since their actions are tied not only to traditional market risk in the form of variable prices, but are also driven by their response to climatic environment and the motivations for holding livestock rather than selling them. Additional considerations also include the minimal investment and asset options to livestock that characterize many rangeland areas of East Africa.

Fafchamps (1998) argues there is considerable evidence that livestock cycles in SATA have as their root cause overgrazing of available pasture (e.g., Doran, Low and Kemp (1979); Sanford (1983), Livingstone (1986, 1991), Jarvis (1993), Swift (1986), Cossins and Upton (1988), and Oba and Lusingi (1987)). Fafchamps (1998) argues further that even though livestock production cycles are usually triggered by two consecutive years of low rainfall after a period increasing livestock numbers, production cycles in SATA “... [fundamentally] result from the accumulation of animals 
beyond the carrying capacity of the range." ${ }^{\prime 18}$ The amplitude of livestock production cycles, and consequently the severity of the resulting circumstances for pastoralists, also appears to increase where there is extensive grazing on common pasture such as is common in SATA (Livingstone (1986); Sandford (1983); and Fafchamps (1998)). The effect that stocking rates - as opposed to strictly climatic events - has on herd welfare and range productivity will be greatest in higher, more stable rainfall areas of our study region, than in the lower, less stable ('disequilibrium') rainfall zones where productivity is mainly driven by climatic events (see Scoones 1995). Nonetheless, policies designed to decrease pastoralists' risk throughout the study region need to account for the joint nature of stocking, household, and common property decisions. For example, programs designed to improve marketing infrastructure without accounting for the potential impact on grazing lands could exacerbate the problem of overgrazing (Fafchamps (1998)). ${ }^{19}$

Since overgrazing is often viewed as the root of many of the economic problems faced by pastoralists, much of the literature suggests government interventions designed to increase the percentage of animals marketed (offtake) over time. Consequently, it is not surprising that the issues of livestock supply response and livestock prices relating to the effects of drought seem to dominate the economic literature allotted to livestock markets in both East and West SATA.

\section{Physical Infrastructural Impediments to Livestock Marketing}

Climate is not the only source of risk in east African livestock systems. Livestock marketing must also overcome a variety of physical infrastructural shortcomings that impede the physical flow

\footnotetext{
${ }^{18}$ Fafchamps indicates this is supported by work completed by Sanford (1983), Turton (1977), and de Leeuw and Tothill (1990).

${ }^{19}$ If infrastructure is improved but rangelands are not, it could lead to even more intense overgrazing in the areas around market locations.
} 
of animals, creating de facto barriers to domestic trade. The most important physical infrastructural weaknesses for the livestock marketing system in the region relate to transport and holding facilities.

Livestock are either trucked or trekked across open country when moved to market. The road network in northern Kenya is in poor condition, especially in the wake of the El Niño floods of early 1998. In the absence of all-weather tarmac or gravel roads, vehicles move more slowly, are more vulnerable to attack by bandits, ${ }^{20}$ and incur substantially more (and more expensive) maintenance costs. One result is that fewer traders are willing to make the trip. Many communities complain of insufficient access to traders who might purchase their livestock. Drought preparedness projects have therefore occasionally subsidized trader transport costs in order to get them to make buying trips to smaller areas (De Laat 1998). Njiru (p.408, (1983)) reports that Kenyan “. . . traders are never sure that when they take their animals to a market they will find a buyer. The distances involved are usually so high that when the costs of trucking or trekking have been incurred the trader has to sell the animals at any price. It would not be profitable for them to return the animals." Moreover, when they arrive at market centers they may find that grazing and water are scarce and expensive to purchase.

This highlights a related problem of "hold-ups." Economic contract theory suggests that when one party to a contract must incur sunk costs prior to its counterparty's own commitment of funds, the latter can use this to his/her advantage in renegotiating contractual terms, especially if opting out of the contract forces the first party to also incur sunk exit costs. In effect, exit costs (in this case, the costs of moving livestock back to pasture from market) render supply considerably more price inelastic, conferring market power on buyers. Sunk entry costs (the costs of moving

\footnotetext{
${ }^{20}$ Banditry is not an issue in southern Ethiopia, so this comments refers to conditions in northern Kenya (Mahmud (1999)).
} 
livestock to market) and pastoralists' recognition of this potential problem — and their impotence to change the sequencing or magnitude of these costs - lowers marketing volumes (i.e., fewer contracts) in equilibrium. The relevance is immediate to livestock marketing in a region with rudimentary infrastructure and, therefore, high sunk transport costs (not to mention physical security risks, a point to which we turn below). A vicious cycle results. High sunk costs and associated holdup problems reduce marketing volumes, which in turn lower investment in slaughtering capacity, which makes processor demand price inelastic as marketed volumes increase, leading to price crashes. Furthermore, reduced marketing volumes depress the returns to investment in infrastructure that might reduce sunk costs, trapping the system in a vicious cycle of high intermediation costs, inelastic demand and supply, and considerable price variability.

Another consequence of poor transport infrastructure is that sellers and traders commonly opt for trekking over trucking animals. Data provided by GTZ-MDP indicate an overwhelming majority (about 85\%) of animals sold in Marsabit in 1996 were trekked from market. Trekking has high costs, in terms of animal mortality and weight loss, trekker time, greater risk of raiding, and environmental and social stress along trekking routes. But without better institutional or physical infrastructure, the cost and availability of motorized transport services precludes more socially efficient, environmentally friendly, and less risky forms of livestock transport. Transport costs are unusually high on a relative basis, ranging from 15-80 per cent of the terminal market price in Nairobi. For example, in Kenya's Isiolo District during 1990, trucking accounted for between 50\% and $80 \%$ of marketing costs for pastoralists, depending on location, and amounted to about $13 \%$ to $18 \%$ of the total value of small stock and over $9 \%$ of the value of cattle. Total transactions costs for marketing livestock in the Isiolo District during 1990 were between $20 \%$ and $25 \%$ of the livestock's value (Ministry of Agriculture, Livestock Development, and Marketing (1993)). By contrast, 
trucking costs and total transaction costs in U. S. cattle markets during the same time period averaged approximately $3 \%-4 \%$ and $10 \%$ of the value of the cattle being sold, respectively (Bailey, Peterson, and Brorsen (1991)).

Transport infrastructure is not the only important weakness. Other than at the closed KMC facilities and at one other slaughter facility in Nairobi, there are no feeding facilities in the Nairobi area for livestock awaiting slaughter. Abattoir sites double as market sites for live animals, and are also considered as quarantine sites. This means that livestock delivered to these sites can not be legally moved out again. ${ }^{21}$ This effectively eliminates other market alternatives once livestock arrive on site. Traders selling cattle at Dagoretti, just outside of Nairobi, routinely face this problem. ${ }^{22}$ The market space is rather small and there are no feeding facilities. Consequently, when daily livestock deliveries exceed daily slaughter capacity sellers are placed in a weak bargaining position since the livestock cannot easily be moved to an alternate market, although traders will occasionally move their animals to Njeru market, north of the city, when market conditions are unfavorable at Dagoretti. Add to this constraint the fact that the condition of animals trekked or trucked long distance degrades rapidly without rest or water (and because of the cooler conditions in Nairobi than in the lowlands from which most of the livestock originate). Improved holding facilities in the Nairobi area or in areas outside of Nairobi may help Nairobi's livestock markets to be more efficient (Chabari (1998)).

Institutional Barriers: Market Information, Contracts, Security, and Animal Disease Control

\footnotetext{
${ }^{21}$ Especially if they originated or mixed with livestock from north of Nairobi because the whole of northern Kenya is under permanent quarantine for Contagious Pleuro-pneumonia (CBPP).

${ }^{22}$ Dagoretti is used as an example here. Since Dagoretti lies to the south of Nairobi other markets like Nejru and Kariobangi are more important for northern Kenyan livestock. There are no holding facilities at Kariobangi, Nairobi's main small stock market.
} 
Efficient arbitrage depends fundamentally on pastoralists and/or traders having access to reliable information on market conditions, especially prices, prevailing at multiple locations. There is evidence that market information reduces market risk. ${ }^{23}$ The efficiency of market information in the study area—most notably, as manifest in the efficiency of price transmission between markets -has not be quantified. For several years, GTZ-MDP funded the collection, processing, and dissemination of market information (of prices, animal conditions, etc. for a variety of species) in the study area. The dissemination process undertaken by GTZ-MDP was not extremely intensive and was limited to posting information notices at Marsabit, Moyale, Korr, and Kalacha, yet the information was used extensively, especially by traders. Market information was also broadcast weekly on the GTZ-MDP and National Radio networks in the Rendille and Boran languages. The radio broadcasts were popular but had limited impact because of the limited number of radios among the pastoral community (Chabari (1999)). However, by the end of GTZ-MDP's sponsorship period, the Kenya Broadcasting Corporation was willing to continue broadcasting market information without charge due to the high demand for the information from people in the region. The county council and traders in Moyale agreed to support the dissemination of market information from Nairobi by agreeing to fund the service with Ksh. 5.00 for each head of cattle sold in Moyale. There is also some evidence to suggest more movement of livestock from traditionally low-priced areas to high priced ones occurred after the introduction of GTZ-MDP's market information program.

Price broadcasting is one means of dissemination of market information. Another occurs at a much more local level— the means of price formation and discovery within a particular market. Livestock transactions take many forms across the study area. Some places-e.g., Marigat, Suguta

\footnotetext{
${ }^{23}$ For example, Smyth (1973); Stein (1992); and Bailey and Brorsen (1998) suggest that market information reduces market price variability.
} 
Marmar (Samburu), Moyale—-have well established livestock auctions that ensure all participants have equal information about current pricing conditions. In other places, traders engage in one-onone negotiation with sellers, which often confers a significant informational advantage on the trader who has been actively dealing with relatively more parties. If possible, it would be fruitful to analyze transactional data from different types of markets to see whether price dispersion (i.e., price risk) is less (as one would expect) in markets based on auctions. GTZ-MDP has sponsored livestock auctions in several remote locations and found that prices paid for livestock during the auctions were dramatically higher than prior to the auction (Chabari (1998)).

Overall, the limited coverage of auctions or other forums for public price formation and discovery, as well as of market information broadcasting or dissemination services suggests that inefficiencies may continue to exist in the study area because accurate market information is not readily available to buyers and sellers. These are services that can be provided at relatively low cost by local governments, producer cooperatives, or NGOs, if central government is unwilling to invest in these improvements in institutional infrastructure.

Weak public information systems and the absence of a credible means to enforce spot market livestock contracts through the legal system contribute to the importance of informal networks among traders. As noted earlier, these networks often are defined by ethnicity, clan, or some other social affinity that encourages cooperation among distant parties otherwise vulnerable to "hold-up" problems of the sort described earlier, and enables individuals to monitor each other effectively and to enforce contracts extrajudicially through third parties. These networks create important barriers to entry for outsiders wishing to break into the marketing channel, but within the networks costs of information and enforcement are substantially reduced. 
Physical insecurity — the risk of banditry and violence — compounds the problems created by weak physical infrastructure and high market transaction costs. Livestock raiding - long an activity of young men and a means for settling scores with neighboring clans and ethnic groups - is itself increasingly fuelled by the prospective commercialization of livestock (Fleischer 1998). Yet, because it often develops hand-in-hand with violent banditry fuelled by ubiquitous automatic weaponry in the rangelands, raiding further degrades infrastructure and fuels the costs and risks of market intermediation, igniting a vicious cycle of physical and economic insecurity that further immiserizes pastoralists. Both pastoralists and traders are increasingly scared to engage in long distance transactions, thereby dampening intermarket arbitrage and the efficiency of marketing channels in transmitting signals of relative scarcity or surplus among spatially distinct consumers and producers. Pastoralists' own risk declarations reveal that the poor, defined as those pastoralists with small herds, perceive greater risk of raiding-related violence than do the wealthy (Smith et al. 1999). Moreover, conflict induces pastoralists to settle around towns for security, thereby reducing their access to some of the best pasture and seasonal water sources, hampering animal productivity and hence prices, and contributing to the degradation of the range ecology around towns (Fleischer 1998).

The private and public institutional apparatus in place to address animal health issues affects the marketing channel in several ways. First, the distribution of medicines, dips, etc. from Nairobi to the northern rangelands covers one half of a lorry's roundtrip, leaving the backhaul leg free for the transport of animals. Second, animal health affects animal productivity, thereby influencing pastoralist supply of livestock to the marketing channel and the prices those animals fetch. Third, animal disease control measures create frictions in the marketing system by adding to costs or interrupting the flow of animals between spatially distinct markets. 
Preventive animal disease control through vaccination programs, cattle dips, etc. seems to be on the decline with the sharp reduction of government-sponsored animal health programs in most of our study area, although community-based paraveterinary programs are providing services in some areas previously underserved by public schemes (Gathuma and Mutiga 1997). Low-incomes and low population densities make private provision of preventive veterinary care unprofitable in most of the east African rangelands, hence the dearth of private animal health services.

Partly as a consequence of the decline of preventive animal health care in the region, animal health measures have come to rely more on curative treatment. For the marketing channel, this implies a tilt away from animal health certification and toward quarantines within and between countries have become central to preventing animal disease epidemics. There are animal health related certification requirements in place for some diseases and districts. Presently, Kenya maintains such a permanent quarantine in northern Kenya against contagious bovine pleuropneumonia (CBPP), requiring certification through blood testing of each animal and movement of cleared animals by vehicle to slaughterhouses so as to minimize the risk of transmission of CBPP to the central highlands commercial herds. Such clearance procedures serve as a specific tax per animal, adding to marketing costs. Such restrictions are less disruptive to the marketing channel than absolute quarantines, in which no intermarket passage of animals is permitted, as occurs during food and mouth disease (FMD) or rinderpest outbreaks in the region. Quarantines have been commonplace for some time. For example, Mbogoh (1997) reports that livestock restrictions on movement between the northern Kenyan ASAL and adjoining Laikipia and Meru Districts were imposed 60 times during the period 1984-88.

The distinction between health certification and quarantine policies can perhaps be understood through the application of basic trade theory from economics. Certification and testing 
programs are de facto tariffs that slow animal movement and add to terminal market livestock prices. Quarantines, on the other hand, are de facto binding quotas, in that in practice they forbid the exit of animals from an outbreak region, thereby segmenting markets, interrupting the flow of animals through the (cross-border) marketing channel and contributing to price variability. The magnitude of the effects of quarantine on prices is as yet unknown in the region. We do know, however, that in some parts of northern Kenya such bans result in excessive local stocking rates and large-scale losses when there are even moderate perturbations in rainfall (Little 1992). If the effects of quarantines are large throughout the region, this might suggest that preventive animal health care expenditures that successfully reduce the frequency of recourse to quarantines would be socially optimal to the present approach to animal disease control. This is a hypothesis to be explored. In general, economic theory is clear in its demonstration of the greater efficiency of tariffs, as compared to quotas. Moreover, when certification and testing protocols convey valuable information to consumers as to product quality (e.g., food safety) - a feature especially important when one considers export marketability of animal products - these barriers to trade can in fact be welfare enhancing even though they add to marketing costs (Thilmany and Barrett 1997).

\section{Toward Risk-Reducing Interventions: Preliminary}

\section{Research Needs}

The considerable price risk and costs observed in livestock marketing in east Africa therefore arise naturally from the conjuncture of several factors: pastoralists' multiple objectives in livestock holding, a legacy of limited private marketing capacity, considerable environmental variation, rudimentary physical infrastructure, and weak rural institutions for market information dissemination, price formation and contract enforcement, assurance of physical security, and preventive animal health services. The effect of the factors appears in the form of high transactions 
costs to livestock marketing, significant hold-up problems, inelastic demand and supply that lead to considerable price variability, and low average livestock prices received by pastoralists. The weaknesses of the marketing system impose tremendous direct and indirect costs on east African pastoralists, the region's poorest subpopulation.

So what might be done to ameliorate the situation? The preceding analysis points to many candidate points for intervention by local or national governments or NGOs. But absent a basic foundation of research on the core behavioral and contextual elements of the livestock marketing system of the area, recommendations cannot proceed on more than a speculative basis. Despite the importance of pastoralist livestock production and marketing to the economies of East Africa - perhaps especially in the arid and semi-arid lands such as those of our project study area in northern Kenya and southern Ethiopia - the available literature on the subject of livestock marketing is thin. And as best as we can tell, there is no published work-in journals, government, or donor publications - combining reliable data series with reasonably current analytical methods. In sum, our empirical understanding of livestock marketing systems in the east African ASAL is extraordinarily limited.

The current project therefore enjoys an opportunity to contribute substantively to the advance of practical knowledge about livestock marketing in the region. We see five interrelated topics in need of exploration: (i) patterns of spatial and intertemporal price transmission and market integration to establish the efficiency of existing marketing channels, (ii) pastoralist marketing behavioral patterns (e.g., response to changes in livestock price distributions, to food aid deliveries, to climate forecasts, etc.), (iii) the effects of intra- and inter-household livestock rights and exchanges on animal sales, (iv) the relationship between animal disease control (particularly through 
quarantines), climate, and marketing dynamics, and (v) the structure, conduct, and performance of the livestock marketing channel.

The project needs longitudinal analysis of marketing patterns. Livestock are long-lived assets and the multiple roles they play in the pastoral economy try ii using dynamic stochastic programming methods, following Behrman and Foster. Multiple round household surveys slated to begin in late 1999 should be able to generate sufficient seasonal and interannual variation to enable estimation of these behavioral parameters and thereby to gain a better capacity to predict how pastoralist livestock sales will respond to changes induced by policy reforms or climatic, economic or sociopolitical shocks. Locations for sampling will be selected to account for differences in spatial access to markets, herd compositions, ethnicity, and climatic variability in the study region.

We will pursue (iv) above by fielding trader surveys, looking at transport patterns, financing and security requirements, the role of social networks in marketing channels, the availability of reliable spot market information on a timely basis, the differences between auctions, coops, coordinated/subsidized buying interventions (e.g., DPIRP). Existence and role of mobility and entry/exit barriers (Barrett 1997).

We are interested in determining the relative risk associated with local and central markets since policy remedies are quite different for different types of markets. For example, if the source of market risk is primarily from central markets then external shocks such as exchange rate risk, income shocks, or infrastructure bottlenecks may be the principal reason for price variability in livestock markets. If the primary source of risk is in local markets, then improvements in local market infrastructure and information may help to reduce market risk. We will also examine the impact of quarantines on livestock markets to determine the costs of quarantines and consequently 
the implicit benefits associated with programs designed to control or eradicate livestock diseases in the study area.

Part of our analysis will be to estimate the costs of livestock quarantines. This will be done by comparing relative prices at different market locations just preceding, during, and immediately following livestock quarantines. This will provide an estimate of the loss in revenue per animal in the quarantined areas and also the increased cost of meat in Nairobi. The purpose of this part of the analysis is to estimate the level of investment governments should make in herd health and education programs.

\section{References}

Anderson, David P., James G. Robb, and James Mintert. “The Cattle Cycle.” In Managing for Today's Cattle Market and Beyond. Department of Agricultural Economics, University of Wyoming. 1997.

Baier, S. An Economic History of Central Niger. Clarendon Press: Oxford. 1980.

Bailey, DeeVon, and B. Wade Brorsen. "Trends in the Accuracy of USDA Production Forecasts for Beef and Pork." Journal of Agricultural and Resource Economics 23(December 1998):51525 .

Bailey, DeeVon, Monte C. Peterson, and B. Wade Brorsen. "A Comparison of Video Cattle Auction and Regional Market Prices." American Journal of Agricultural Economics 73(May 1991):465-75.

Barrett, C.B."Market Analysis Methods: Are Our Enriched Toolkits Well-Suited To Enlivened Markets?" American Journal of Agricultural Economics 78 (August 1996):825-829.

Barrett, C.B., "Food Marketing Liberalization and Trader Entry: Evidence from Madagascar," World Development 25 (May 1997): 763-777.

Barrett, Christopher B., Peter D. Little, DeeVon Bailey, Francis Chabari, and Kevin Smith. "How Might Infrastructure Improvements Mitigate the Risks Faced by Pastoralists in Arid and Semiarid Lands?" Ruminations (Newsletter of the USAID Global Livestock/Small Ruminant CRSP), Fall 1998, pp. 1, 10, 1-13. 
Bille, J. C. "The Climatic Risks to Livestock Production in the Ethiopian Rangelands." JEPSS (Joint Ethiopian Pastoral Systems Study) research Report 4, International Livestock Centre for Africa, Addis Ababa, Ethiopia. 1983.

Binswanger, H. and J. McIntire, 1987. Economic Development and Cultural Change.

Bromley, D.W. and J.-P. Chavas, "On Risk, Transactions, and Economic Development in the Semiarid Tropics," Economic Development and Cultural Change 37 (October 1989): 719736.

Chabari, Francis. GTZ-Marsabit Development Programme. Personal communication. December 1998.

Chavas, J.P. "Production and Investment Decisions Under Sunk Costs and Temporal Uncertainty." American Journal of Agricultural Economics 76 (1994):114-127.

Coppock, D. Layne. “Culture, Environment, Technology: Development Interventions in Pastoral Ethiopia.” National Geographic Research \& Exploration 8(1992):296-307.

Coppock, D. Layne. The Borana Plateau of Southern Ethiopia: Synthesis of Pastoral Research, Development and Change, 1980-91. International Livestock Centre for Africa, Addis Ababa, Ethiopia. 1994.

Cossins, N. J., and M. Upton. "The Impact of Climate Variation on the Borana Pastoral System." Agricultural Systems 27(1988):117-35.

de Laat, Joost J. "Evaluation of the 1996 Emergency Livestock Off-Take In Merti- and Sericho Division, Isiolo District and Analysis of the 1998 Livestock Marketing Situation in Mertiand Sericho Division." Thomas J. Watson Foundation. DPIRP,, Nanyuki, Kenya. September 2, 1998.

de Leeuw, P. N. and J. C. Tothill. The Concept of Rangeland Carrying Capacity in Sub-Saharan Africa - Myth or Reality. Overseas Development Institute, Pastoral Development Network. May 1990.

Dercon, S., "Wealth, Risk and Activity Choice: Cattle in Western Tanzania," Journal of Development Economics 1998.

Dixit, A. and R. Pindyck. Investment Under Uncertainty. Princeton: Princeton University Press, 1994.

Doran, M. H., A. R. C. Low, and R. L. Kemp. "Cattle As a Store of Wealth in Swaziland: Implications for Livestock Development and Overgrazing in Eastern and Southern Africa." American Journal of Agricultural Economics 61(February 1979):41-47. 
Edwards, Sue andTafesse Mesfin, eds. Conference on Pastoralism in Ethiopia: Full Papers. Addis Ababa: Ministry of Agriculture. 1996.

Ensminger, Jean. Making a Market. University of Cambridge Press: Cambridge. 1992

Fackler, P.L. and B.K. Goodwin, "Spatial Price Analysis," February 1999 mimeo.

Fafchamps, Marcel. "The Tragedy of the Commons, Livestock Cycles, and Sustainability.” Journal of African Economies. Forthcoming.

Fafchamps, Marcel and Sarah Gavian. "The Determinants of Livestock Prices in Niger." Journal of African Economies 6(1997):255-295.

Fafchamps, Marcel, Christopher Udry, and Katherin Czukas. "Drought and Saving in West Africa: Are Livestock a Buffer Stock?” Journal of Development Economics 55(1998):273-305.

Fekade, Tilahun. "Transforming the Ethiopian Pastoral Economy: A Preliminary Assessment of Urban-Rural Linkages in Predominantly Pastoral Economies," A Paper prepared for the Fourth Annual Conference on the Ethiopian Economy, Debre-Zeit, Ethiopia. 1994

Fleischer, M.L. "Cattle Raiding and Its Correlates: The Cultural-Ecological Consequences of Market-Oriented Cattle Raiding Among the Kuria of Tanzania," Human Ecology 26: 547572.

Franke, C. "The Kumasi Cattle Trade.” Ph. D. thesis. New York University, New York. 1982.

Gathuma, J.M. and E.R. Mutiga. "Impact of Major Diseases Affecting Livestock Productivity Under Nutritional Stress and Livestock Migration," paper presented to the ASARECA/ILRI workshop on Crisis Mitigation in Livestock Systems in the Greater Horn of Africa, 6-12 July, 1997, Nyanyuki, Kenya.

GTZ-Marsabit Development Programme. Livestock Disease Quarantine Information, 1991-98. Personal communication. August, 1998.

Herman, L. The Livestock and Meat Marketing System in Upper Volta: An Evaluation of Economic Efficiency. Center for Research on Economic Development, University of Michigan, Ann Arbor, Michigan. 1983.

Holtzman, John S., and Nicolas P., Kulibaba. "Livestock Marketing in Pastoral Africa: Policies to Increase Competitiveness, Efficiency and Flexibility." In Living With Uncertainty: new Directions in Pastoral Development in Africa, I. Scoones (Ed.), Intermediate Technology Publications: London, England. 1994.

Holtzman, J. S., J. P. Kulibaba, and C. J. D. Stathacos. Livestock Marketing and Trade in the Central Corridor of West Africa. Agricultural Marketing Improvement Strategies Project, 
Sahel West Africa Office, USAID, Washington DC, and Abt Associates, Bethesda, Maryland. 1992.

Holtzman, J. S., J. Staatz, and M. T. Weber. "An Analysis of the Livestock Production and Marketing Subsystem in the Northwest Province of Cameroon.” MSA Rural Development Working Paper 11. Department of Agricultural Economics, Michigan State University, East Lansing, Michigan. 1980.

Hutchinson, Sharon. Nuer Dilemmas: Coping with Money, War, and the State. University of California Press: Berkeley. 1996.

Intergrated Project in Arid Lands (IPAL). The Economics of Pastoralism in Northern Kenya: The Rendille and the Gabbra, Technical Report Number F-3. Nairobi. 1984.

Kervan, C. Customary Commerce: A Historical Reassessment of Pastoral Livestock Marketing in Africa. ODI Agricultural Occasional Paper 15. London, 1992.

Ministry of Agriculture, Livestock Development, and Marketing. Republic of Kenya. Range Management Handbook of Kenya. Nairobi. 1993

Jabbar, M. A. "Buyer Preferences for Sheep and Goats in Southern Nigeria: A Hedonic Price Analysis.” Agricultural Economics, 18(1998):21-30.

Jabbar, M. A. "Market Niches for Increased Small Ruminant Production in Southern Nigeria." Oxford Agrarian Studies, 23(1995):85-96.

Jabbar, M. A., B. M. Swall, G. d. M. d'leteren, and A. A. Busari. "Farmer Preferences and Market Values of Cattle Breeds of West and Central Africa." Socioeconomic and Policy Research, Working Paper No. 21. Livestock Policy Analysis Programme, International Livestock Research Institute, Addis Ababa, Ethiopia. May 1997.

Jarvis, L. "Overgrazing and Range Degradation in Africa: Is There Need and Scope for Government Control of Livestock Numbers?” East Africa Economic Review (1993):95-116. Nairobi.

Kenya Meteorological Department. Monthly rainfall totals for Moyale and Marsabit. Data provided by Dr. Francis Chabari. July 1998.

Konczacki, Zbigniew A. The Economics of Pastoralism. Frank Cass Press: Totowa, NJ. 1978.

Li, J.-R. and C. B. Barrett. "Distiguishing Between Equilibrium and Integration in Market Analysis." Selected paper, annual meetings of the American Agricultural Economics Association, Nashville, TN. August 1999.

Little, Peter D. "Absentee Herd Owners and Part-time Pastoralists: The Political Economy of Resource Use," Human Ecology 13(1985):131-151. 
Little, Peter D. The Elusive Granary: Herder, Farmer, and State in Northern Kenya, Cambridge University Press: Cambridge. 1992.

Little, Peter D. Cross-Border Cattle Trade and Food Security in the Kenya/Somalia Borderlands, Institute for Development Anthropology: Binghamton. 1996.

Little, Peter D., Tegegne Teka, and Alemayehu Azeze, "Research Methods on Cross-Border Trade in the Horn of Africa: Further Observations," Paper prepared for the Cross Border Trade and Food Security Study, Broadening Access to Input Systems Markets (BASIS) CRSP and The Organization for Social Science Research in Eastern and Southern Africa (OSSREA), 1998.

Livingstone, Ian "Livestock Management and 'Overgrazing' Among Pastoralists." Ambio, 20(1991):80-85.

Livingstone, Ian. “The Common Property Problem and Pastoralists Economic Behaviour." Journal of Development Studies 23(1986):5-19.

Mahmud, Ahmed. Personal communication. March 1999.

Mariam, Sintayehu Gebre. "Livestock Marketing in Pastoral Areas of Ethiopia," Conference on Pastoralism in Ethiopia, 4-6 February 1993. Ministry of Agriculture/Oxfam/IIED/Save the Children (USA): Addis Ababa. 1996.

Mbogoh, S. G. "Effects of Drought and Other Types of Crises on Livestock Production and Marketing in the Greater Horn of Africa With Particular Reference to Experiences in Kenya and Northeast Africa," Paper presented to the ASARECA/ILRI workshop on Crisis Mitigation in Livestock Systems in the Greater Horn of Africa, 6-12 July, 1997, Nyanyuki, Kenya.

Ministry of Planning and National Development, Republic of Kenya. 1989-93 Isiolo District Development Plan. Nairobi..

Mutea, J.A. and V.K. Lelei. Arid Lands Project: Livestock Marketing Component. Government of Kenya, Office of the President, Drought Recovery Programme working paper no. 3.

Nicholson, Charles F., Getachew Gebru, Simeon K. Ehui, Barry I. Shapiro, and Christopher Delgado. "Producer Milk Groups in Ethiopia's Highlands: A Framework for Assessing Impacts and a Review of Group Performance." Paper presented at a workshop on the Role of Village Cooperatives in Dairy Development: Prospects for Improving Dairy in Ethiopia. Organized by Smallholder Dairy Development Project (SDDP), Animal and Fisheries Resource Development and Regulatory Department, Ethiopian Ministry of Agriculture, Addis Ababa. 22-24 April 1998. 
Njiru, G. K. 'Chapter V, 'Marketing and Infrastructure' and Section A (Forestry) and B (Agriculture) of Chapter VI, 'Other Land Uses'." In Integrated Resource Assessment and Management Plan, for Western Marsabit District Northern Kenya. 1983.

Oba, G., and W. J. Lusingi. An Overview of Drought Strategies and Land Use in African Pastoral Systems. Pastoral Development Network. March 1987.

Raynaut, Cl. "Le Cas de la Region de Maradi." In Copans, J. (ed.), Secheresses et Famines du Sahel, Maspero: Paris, pp. 3-43. 1975.

Reardon, Thomas and Peter Matlon. "Seasonal Food Insecurity and Vulnerability in DroughtAffected Regions of Burkina Faso." In: David, S. (Ed.), Seasonal Variability in Third World Agriculture: the Consequences for Food Security. Johns Hopkins University Press: Baltimore, Maryland. 1989.

Reardon, Thomas, Christopher Delgado, and Peter Matlon. "Determinants and Effects of Income Diversification Amongst Farm Households in Bukina Faso." Journal of Development Studies 28(Jan 1992):264-96.

Rosen, Sherwin, Kevin M. Murphy, and Jose A. Scheinkman. "Cattle Cycles.” Journal of Political Economy 102(1994):468-92.

Sandford, Stephen. Pastoral Strategies and Desertification: Opportunism and Conservation in Dry Lands. In B. Spooner and H.S. Mann (eds), Desertification and Development, Academic Press: London. 1982.

Sandford, Stephen. Management of Pastoral Development in the Third World. John Wiley \& Sons: Chichester, England. 1983.

Scoones, Ian, ed. Living With Uncertainty: New Directions in Pastoral Development in Africa. Intermediate Technology Publications: London. 1995.

Sen, A. Poverty and Famines. Clarendon Press: Oxford, England. 1981.

Smith, Kevin, Christopher B. Barrett, and Paul W. Box, "Participatory Risk Mapping for Targeting Research and Assistance: An Application Among East African Pastoralists," mimeo, January 1999.

Smyth, D. J. "Effect of Public Price Forecasts on Market Price Variation: A Stochastic Cobweb Example.” American Journal of Agricultural Economics, 55(February 1973):83-88.

Staal, Steven, Christopher Delgado, and Charles Nicholson. "Smallholder Dairying Under Transaction Costs in East Africa." World Development, 5(1997):779-94. 
Staal, Steven J., and Barry I. Shapiro. "The Effects of Recent Price Liberalization on Kenyan PeriUrban Dairy." Food Policy, 19(1994):533-49.

Staatz, J. The Economics of Cattle and Meat Marketing in Ivory Coast. Center for Research on Economic Development. University of Michigan, Ann Arbor, Michigan. 1979.

Stein, J. L. "Cobwebs, Rational Expectations and Futures Markets." Review of Economics and Statistics, 71(February 1992):127-34.

Surtech Consulting Engineers. Isiolo Meat Factory Project: Feasibility Study for Isiolo Abattoir. Report prepared for the GTZ-Marsabit Development Programme. 1993.

Swift, Jeremy. "The Economics of Traditional Pastoralism: the Twareg of the Adrar n Iforas (Mali)." Ph. D. thesis. University of Sussex, England. 1979.

Swinton, Scott M. "Drought Survival Tactics of Subsistence Farmers in Niger." Human Ecology 16(1988):123-44.

Thilmany, D.D. and C.B. Barrett. "Regulatory Barriers In An Integrating World Food Market," Review of Agricultural Economics 19 (1997): 91-107. [And correction to printer's errors 19 (1997): 504.]

Toulmin, Camilla. "Tracking Through Drought: Option for Destocking and Restocking." In Living with Uncertainty: New Directions $n$ Pastoral Development in Africa, I. Scoones (Ed.), Intermediate Technology Publications: London, England. 1994

Turton, D. "Response to Drought: The Mursi of Southwestern Ethiopia.” Disasters, 1(1977):27587.

Udry, Christopher. "Risk and Saving in Northern Nigeria." American Economic Review 85(December 1995):1287-1300.

Union International Consultants. The Kenya Meat Commission: A Viable Future. 1989.

van Apeldoorn, G. J. Perspectives on Drought and Famine in Nigeria. Allen \& Unwin: London. 1981.

Watts, M. J. "The Demise of the Moral Economy: Food and Famine in the Sudana-Sahelian Region in Historical Perspective. In Scott, E. (ed.), Life Before the Drought. Allen \& Unwin: Boston, pp. 124-148. 1984.

Webb, P., J. von Braun, and Y. Yohannes. "Famine in Ethiopia: Policy Implications of Coping Failure at National and Household Levels." Research Report, Washington, DC. 1992. 
Williams, Timothy O. "Livestock Pricing Policy in sub-Sahara Africa: Objectives, Instruments and Impact in Five Countries." Agricultural Economics 8(1993):139-59. 